In studying this species, the experiments were conducted under laboratory conditions where the temperature varies. Temperature readings during day were between $60-80$ degrees and during the night between 40-50 degrees Fahrenheit. Observations were made on forty-seven eggs, twenty-two hatched and transformed into adults. The life cycle according to observations under these conditions required an average period of thirty-eight days.

Explanation of Plate 15

No. 1. The egg in situ on leaf. (Much enlarged.)

2. Cocoon. (Much enlarged.)

3. Pupa. (Mueh enlarged.)

4. Larva. (Much enlarged.)

5. Adult. (Much enlarged.)

6. Cocoon with top dissected away to show pupa. (Much enlarged.)

7. Showing pupa encased in cocoon. (Slightly enlarged.)

\title{
THE MOUTHPARTS OF THE THYSANOPTERA AND THE RELATION OF THRIPS TO THE NON-SETTING OF CER- TAIN FRUITS AND SEEDS
}

\author{
By Arthur D. Borden, Pasadena, California
}

The asymmetry of the mouthparts of the Thysanoptera has been known for a long time, and a number of papers have been published describing in more or less detail the general characters of the mouthparts. In the present paper is presented a detailed account of the mouth structure of the thrips based on a considerable comparative study of the mouthparts. It also includes some observations on the feeding habits and on the damage done by certain of the economically important species. As examples of what serious pests are contained in this group of insects, there need only be mentioned the pear thrips (Euthrips pyri), the wheat thrips (Euthrips tritici), the orange thrips (Euthrips citri), the grass thrips (Anaphothrips striatus), the onion thrips (Thrips tabaci), the tobacco thrips (Euthrips fuscus), the greenhouse thrips (Heliothrips hamorrhoidalis), and the bean thrips (Heliothrips fasciatus). Nearly all of these are recognized as pests in the state of California.

The earliest considerable description I have been able to find of the mouthparts is that of Karl Jordan (1888), on Parthenothrips dracance, a fairly accurate description and quite well illustrated. Then came the account of H. Garman (1890), on Limothrips cerealium, who points out the error in considering the articulated lobes of the maxillæ as the mandibles, and suggests that the unpaired organ is truly the mandible. In $1891 \mathrm{~J}$. Bohls published as a doctor's dissertation at 

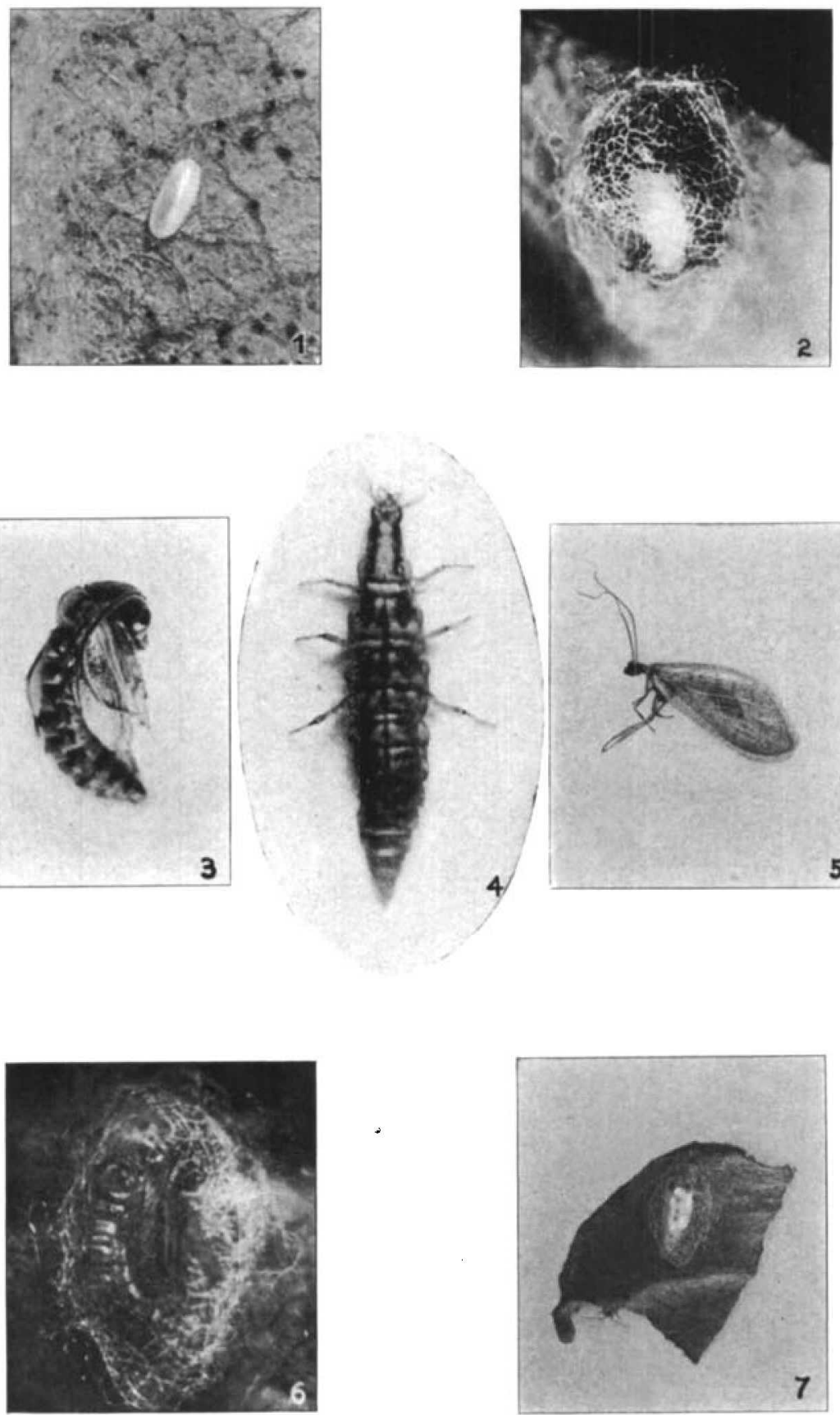

Brown Lace Wing 
Göttingen an account of the mouthparts. Then follows the account in Uzel's Monograph (1895) in which Uzel adopts Garman's views as to the structure, excepting that he differs with Garman in regard to the mandibles, Uzel holding that the lobes of the maxillæ are the mandibles and calling the mandible of Garman the epipharynx. Garman again presented his theory, in the American Naturalist (1896), and offered a strong argument to support his views. In 1899, Pietro Buffa, an Italian, described the structure of Heliothrips hamorrhoidalis, giving a fairly accurate description, although his illustrations are confusing. Finally, in 1902, W. E. Hinds gave a very good description of the structure of the mouthparts of Anaphothrips striatus, but his figure is at most only diagrammatic. Very little comparative work had been attempted before the work of Hinds.

The present work is based on studies made of representatives of all three families of the Thysanoptera, including twelve of the genera and some twenty odd species. The material was all collected in the Santa Clara Valley, California. The method employed in collecting and preparing was as follows: The thrips were collected and killed by dropping them directly into 70 or 80 per cent alcohol; dehydrated by passing them successively through 90,95 and absolute alcohol, then cleared in xylol and mounted in balsam. As soon as mounted, the mouthparts may be separated out by carefully pressing and moving the cover slip with a needle, under the low power of the compound microscope, until it can be seen that the parts are sufficiently separated. In some cases the specimens were cleared by boiling in $\mathrm{KOH}$ a few seconds before mounting.

The work and preparation of this paper were carried on in the Entomological Laboratory of Stanford Cniversity.

\section{The Mouthparts}

The mouthparts of the thrips appear as a broad unjointed cone attached to the extreme posterior edge of the under side of the head and carried so far back that it lies largely under the pronotum when at rest. The apex of the cone is usually quite sharp, as in many of the Phloothripidæ, in which case the separate parts are longer and more tapering than where the tip of the cone is more blunt, as in many of the Thripidæ. The shape of the cone is not of the same type throughout any one large group or even for the different families, but varies greatly even for the different genera in the same family.

In the suborder Terebrantia, the mouthparts are connected to the frons by a strongly chitinized thickening rounding the head ( $\mathrm{Pl}$. 16, figs. $1, e$ and $2, e$ ) which is more or less oblique on the front of the head. In this suborder there is also a strongly chitinized thickening extending 
from this circular band to the left eye (Pl. 16, figs. $1, b$ and 2, $b$ ) and a rudiment of one under the right eye (Pl. 16, figs. 1, $a$ and 2, a). At each side of the head and extending a short way down the side of the mouth cone is a peculiar curved spine which may possibly serve as a strengthening rod to the side of the cone (Pl. 16, fig. 2, d). The suborder Tubulifera has the connection with the eye wanting.

The general makeup of the mouthparts of the different species is quite similar, the greatest difference occurring in the shape of the parts in those species where the cone is blunt instead of sharp. In the former case, the separate parts are heavier and broader and necessarily shorter. There is also some difference in the number of segments of the labial and maxillary palpi, as will be noted later. The mouthparts of the young are similar to those of the adult, though less strongly chitinized.

As to the asymmetry of the mouthparts, I have adopted Garman's views and consider the unpaired organ on the left side as the mandible. The labrum and the clypeus also show asymmetry and these will be discussed separately.

LABRUM.-The labrum (Pl. 16, fig 1,l) forms the front of the cone and is asymmetrical in all the thrips. It is composed of two segments closely united and is distinguished from the clypeus (Pl. 16, figs. 1, $c$ and $2, c$ ) by a membranous connection. It is long, slightly curved and bears at the tip a round socket through which the stylets pass (PI. 16 , figs. 3 and $3, a$ ). So far as I know, this condition has not been pointed out before. The labrum is drawn out on the right side and nears the edge of the clypeus. The clypeus is decidedly asymmetrical and curves high on the left side, thus forming the broad part of the membranous connection between it and the labrum.

MaxiLLe.-The maxilla (Pl. 16, figs, 1, $g$ and 4) form the side walls of the mouth cone. They are triangular in form, and taper strongly towards their tips which fit closely about the tip of the labrum. About the middle of the maxillæ are borne the maxillary palpi (PI. 16, fig. 4, b) which bear a few tactile hairs. The maxillary stylets, or lobes (Pl. 16, figs. 1, $i$ and 4, $i$ ), are borne at the top and are jointed, being composed of a short stout arm and a long tapering stylet. By lowering the angle of the short arm with the main part of the maxillæ, the stylets are thrust out. The segments in the maxillary palpi differ greatly in number and shape with different genera, even in the same family. For example, in the family Aeolothripidæ, members of the genus Orothrips have seven segments, of the genus Erythothrips eight segments, and of the genus Aelothrips three segments. The usual number in the family Thripidæ is three although often only two occur. In the family Phlœothripidae the usual number is two. 
The segments may be short and stout, as in the genus Orothrips, or they may be long and cylindrical as in many of the genera of the Thripidæ.

LABICM.-The labium (Pl. 16, figs. 1, $a, 7$ and 7, a) forms the hind wall of the mouth cone. Where the mouth cone is blunt, the labium is usually very broad and heavy, and where the mouth cone is sharp, the labium is narrowed. The labial palpi (Pl. 16, figs. $1, k$ and $7, k$ ) are borne near the tip, and the very tip of the labium is lobed and bears a tactile hair on each tiny lobe. There is a strong chitinous bar (Pl. 16, figs. $7, a-n$ ) extending down near the median line of the labium which divides near its base and ends in two peculiar, spear-shaped parts. This bar is undoubtedly a strengthening device for the fleshy labium. The labial palpi differ as greatly as do the maxillary palpi within the different families. In the Phlœothripidæ they are usually described as having but one segment and in the Thripidæ usually two, while in the family Oelothripidæ the genus Orothrips bears five segments and the others but four. In most Thripidæ that I have examined there seems to be but a single segment composing the labial palpus.

Within the hollow of this mouth cone we find the maxillary stylets already described, the single mandible on the left side, and an organ which I have taken to be the hypopharynx.

Mandible.-This is a large, strongly chitinized, styliform organ on the left side (Pl. 16, fig. $1, f$ ) and joined by its broad base to the chitinous band in the frons just where the connection is made with the bar running to the left eye. The mandible is peculiarly fitted to this side of the head, and I have been unable to find anything corresponding to it on the right side, though scveral authors have described a rudimentary part. Although the mandible may differ slightly in shape in the different groups, the structure is essentially the same throughout. It is made up of a bulbous chitinous base with a strong muscular attachment and a long sharp stylet slightly angled at its base.

Hypopharynx.- Just below the mandible and on the base of the mouth opening, viewing the mouthparts from the front, is a large styliform organ passing through a groove or socket (which is attached to the floor of the mouth opening) and with a strong muscular attachment reaching well up under the frons of the head. This I take to be a hypopharynx. It has been only partially described before. Jordan describes the upper section and suggests that it is a hypopharynx; Buffa describes it in part and also figures an epiglottis; Hinds simply mentions it but does not attempt to describeit. In none of the accounts has it been described as styliform as I have found it in my preparations. This I take to be used much as is the mandible in feeding. 

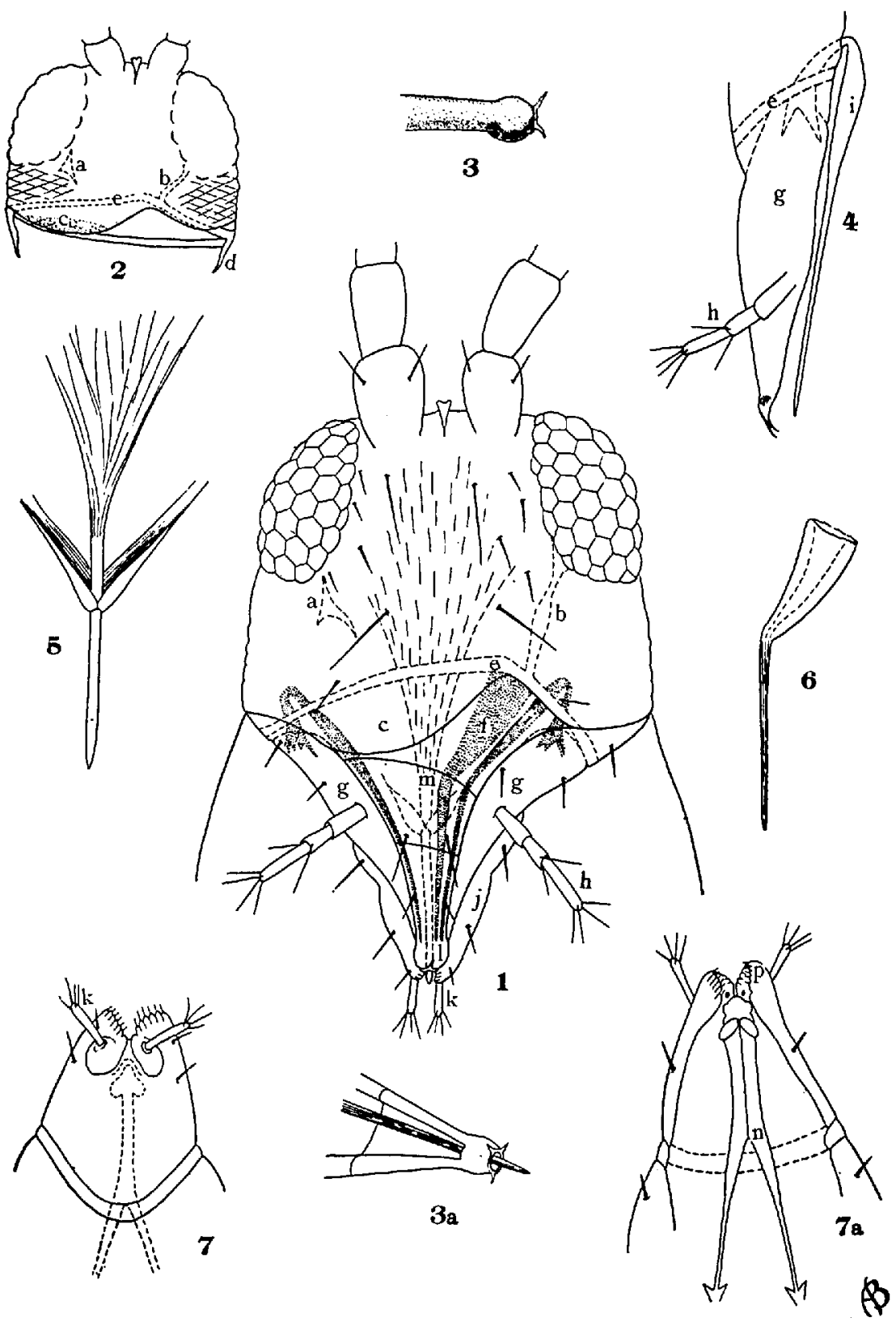

Euthrips tritici 


\section{Observations on Feeding Habits}

The mouthparts of the Thysanoptera are probably used almost entirely for sucking although they have been repeatedly described as intermediate in form between those of sucking and chewing insects. In feeding, the insect begins by a forward and backward movement of the head and by this sort of rasping movement punctures the epidermal cells of the plant tissue. It then lowers its head and begins to suck up the plant juices. It remains here until the punctured cells are nearly emptied when it moves on a bit and repeats the operation. From the structure of the mouthparts it appears that the strong mandible and possibly the hypopharynx are used in breaking the cells of the tissues, while the finer stylets of the maxillæ are using in lancing the softer tissues. The tip of the labrum placed over the puncture forms a close connection and the juices are easily sucked up into the mouth. The whole mouth cone is fitted for sucking and most likely the food is alnost entirely plant juices. I have made observations on the greenhouse thrips, Heliothrips homorrhoidalis and Parthenothrips draconce on leaves of a greenhouse plant, and also on Euthrips pyri, the pear thrips, on fruit blossoms, as well as Euthrips tritici and Euthrips occidentalis on alfalfa blossoms. The feeding habits of the young are similar to those of the adult.

\section{Results of Feeding on Deciduous Fruits}

On the deciduous fruits the thrips feed on the tender floral parts (the tips of the petals of the opening buds and later on the inner floral parts including the tender stigma) with very damaging results to the setting of the fruit, where the insects occur in any great numbers. The injured tissues at first turn brown and later black, often resulting

\section{Explanation of Prate 16}

Fig. 1. Head of Euthrips iritici: $a$, rudiment of chitinous band to right eye; $b$, chitinous band to lef t eye; $c$, clypeus; $d$, chitinous band under frons; $f$, mandible; $g$, maxilla; $h$, maxillary palpus; $i$, maxillary stylet; $j$, labium $k$, labial palpus; $l$, labrum; $m$, hypopharynx.

Fig. 2. Same with mouth parts removed: $a$, rudiment of chitinous band to right eye; $b$, chitinous band to left eye; $c$, clypeus; $d$, curved spine from chitinous band; e-chitinous band.

Fig. 3. Tip of labrum, side view.

Fig. 3a. Tip of labrum, under-side showing stylets in position.

Fig. 4. Maxilla: $e$, part of chitinous band; $g$, main part of maxilla; $h$, maxillary palpus; $i$, maxillary stylet.

Fig. 5. Hypopharynx removed, showing socket and muscular attachment.

Fig. 6. Mandible removed.

Fig. 7. Labium ventral side.

Fig. 7a. Labium dorsal side, showing chitinous rod $(n)$. 
in premature falling of the flower before setting of the fruit. In the Santa Clara Valley I have examined peach blossoms which contained a great number of thrips and even before the fruit had had a chance to set the damage was so serious that by gently stripping my hand down a twig nearly every blossom would fall. The almonds, the first crop to blossom, are damaged to a slight extent where the thrips occur in numbers, but the prunes, plums, peaches, apricots and cherries, which follow in rapid succession, are the fruits which are damaged the most. This had been an unusual spring (1913) for thrips and they bave done serious damage to crops in the Santa Clara Valley. One orchardist estimated that nearly two-thirds of the "set" on his peach orchard was destroyed by thrips this year. These trees are commonly infested with Euthrips pyri, Euthrips occidentalis, Euthrips tritici, and Oelothrips kuwanaii, though Euthrips pyri occurs in much the greater numbers.

\section{Damage to Alfalfa Grown for Semp}

On alfalfa I have collected quantities of Euthrips tritici and Euthrips occidentalis. Though alfalfa is not grown for seed in the Santa (Hara Valley, I have had a chance to observe the work of the thrips, as the insects occur in considerable numbers there. The damage here is much the same as in the flowers of the deciduous fruits. The young floral parts are attacked, and the damage results in the premature falling of the flower or the young seed pod. Though the ovary is very pubescent I have observed thrips feeding about the base and also along the tender stigma. Often I have found specimens of alfalfa where nearly all the small pods had dropped from the main stem and only a few remained near the tip. Where this damage could not be directly traced to the feeding of Diabrotica soror, and the thrips were present in great numbers, the damage was most likely the result of thrips attack.

\section{Bibliography}

1888. JoRDAN, KARL. Anatomie und Biologie der Physapoda (Zeitsrh, für wiss. Zool. 47 Bd.).

1890. Garman, H. The Mouthparts of the Thysanoptera (Bulletin Essex Institute, Vol. 22) (Canadian Entomologist, Vol. 22)

1891. Bonls, J. Die Mundwerkzeuge der Physapoden (Dissert. Göttingen).

1895. Uzes, H. Monographie der Ordnung Thysanoptera.

1896. Garman, H. The Asymmetry of the Mouthparts of the Thysanoptera (American Naturalist, Vol. 30).

1899. Bufra, Pistro. Contributo allo studia anatomico della Heliothrips hæ morrhoidalis (Revista di Patologia Vegetale, Vol. 7).

1902. Hinds, W. E. Contribution to a Monograph of the Insects of the order Thysanoptera inhabiting North America (Proceedings of the I'nited States National Museum, Vol. 26). 